\title{
Local differences in the epidemiology of traumatic spinal injuries
}

\author{
Spinal yaralanma epidemiyolojisinde yerel farklılıklar
}

\author{
Mehmet Özgür ERDOĞAN, ${ }^{1}$ Sibel ANLAŞ DEMİR, ${ }^{1}$ \\ Mehmet KOŞARGELİR, ${ }^{2}$ Şahin ÇOLAK, ${ }^{1}$ Engin ÖZTÜRK ${ }^{1}$
}

\section{BACKGROUND}

Spinal cord injury (SCI) has a serious lifetime impact as well as obvious social and economic effects for both patients and society. The aim of this study was to collect recent information and analyze changes in the epidemiology of traumatic spinal injuries.

\section{METHODS}

Data included traumatic SCI (TSCI) patients admitted to the emergency department of Haydarpaşa Numune Training and Research Hospital between January 2007 and December 2011. 409 TSCI patients were included in the study. Categorical variables were analyzed with Fisher's exact test and parametric variables with independent samples t test.

\section{RESULTS}

The most common injury mechanism was high falls. 85 $(20.8 \%)$ patients were injured in low falls, which was the second most common injury mechanism. The most common injury was lumbar spine injury (196 [48\%] patients suffered isolated lumbar spine injury), followed by thoracal spine injuries. Lumbar spinal injuries $(p=0.00011)$ were observed at a higher rate in high falls. Low fall was a significant mechanism for thoracal spine injuries $(p=0.003)$. Automobile accidents had a significant relation with cervical $(p=0.00001)$ and lumbar $(p=0.004)$ spinal injuries.

\section{CONCLUSION}

Although cervical injuries were higher in automobile accidents, the ratio of automobile accident-related TSCI was less than reported in other studies. Cervical injury ratio of the population decreased due to the decrease in the number of automobile accident-related TSCIs.

Key Words: City; epidemiology; spinal trauma.

\begin{abstract}
AMAÇ
Spinal kord yaralanması ömür boyu süren etkiye sahiptir. Hastalar ve toplum için ağır sosyal ve ekonomik etkileri vardır. Bu çalışmanın amacı şehir yaşamının travmatik spinal kord yaralanmaları (TSKY) üzerinde yarattığı epidemiyolojik farklılıkları tanımlamaktır.
\end{abstract}

\section{GEREÇ VE YÖNTEM}

Haydarpaşa Numune Eğitim ve Araştırma Hastanesi acil servisine Ocak 2007-Aralı 2011 arasında başvuran 409 TSKY hastası değerlendirildi. Kategorik değişkenler için Fischer kesin testi, parametrik veriler için bağımsız örneklem t-testi kullanıldı.

\section{BULGULAR}

En sık yaralanma şekli yüksekten düşmelerdi, 85 (\%20,8) hasta basit düşme sonucu yaralanmıştı. En sık ikinci yaralanma şekli basit düşmelerdi. Hastaların 196'sı (\%48) lomber spinal yaralanma geçirmişti. En sık lomber spinal yaralanmalar gözlenmişti. Torakal bölge en sık ikinci yaralanan bölgeydi. Lomber spinal yaralanmalar yüksekten düşmelerde daha sıktı ( $p=0,00011)$. Basit düşmelerde torakal bölge yaralanmaları daha sıktı $(p=0,003)$. Otomobil kazalarında belirgin şekilde servikal $(p=0,00001)$ ve lomber $(\mathrm{p}=0,004)$ yaralanmalar daha sikt .

\section{SONUÇ}

Servikal yaralanmalar otomobil kazalarında daha sık olmaktadır. Şehir merkezinde otomobil kazasına bağlı TSKY oranı diğer çalışmalara göre daha azdı. Servikal yaralanma oranıda otomobil kazası ilişkili TSKY oranının azalması ile azalmıştır.

Anahtar Sözcükler: Şehir; epidemiyoloji; spinal travma.
${ }^{1}$ Haydarpaşa Numune Eğitim ve Araştırma Hastanesi, Acil Tıp Kliniği, İstanbul; ${ }^{2}$ Sağlık Bakanlığı Acil Sağlık Hizmetleri Daire Başkanlığı, Ankara. 
Spinal cord injury (SCI) has a serious lifetime impact as well as obvious social and economic effects for both patients and society. No curative treatment is available for the disease. It is thus imperative to be well aware of the etiology in order to develop precautions for the prevention of spinal trauma..$^{[1-3]}$

The aim of this study was to collect recent information and analyze city differences in the epidemiology of traumatic spinal injuries. Improvement in prevention strategies must be the main concern for the management of spinal trauma.

\section{MATERIALS AND METHODS}

Road traffic accidents (RTAs) were grouped as car, motorcycle or pedestrian accidents. Falls were divided as high falls $(>1 \mathrm{~m})$ and low falls $(<1 \mathrm{~m})$. All sportsrelated injuries were grouped as sport injuries. All patients were defined according to American Spinal Injury Association Impairment Scale (ASIA) at discharge from the hospital. Data included all traumatic SCI (TSCI) patients admitted to the emergency department (ED) of Haydarpaşa Numune Training and Research Hospital between January 2007 and December 2011. Four hundred and nine TSCI patients were included in the study.

Data were analyzed using the Statistical Package for the Social Sciences (SPSS) ver. 17.0. Categorical variables were analyzed with Fisher's exact test and parametric variables with independent samples $t$ test. The level of significance was set at 0.05 .

\section{RESULTS}

There were $253(61.9 \%)$ males and $156(38.1 \%)$ females. The male to female ratio was $1.6 / 1$. The average age was $46.82 \pm 19.05$ years $(43.75 \pm 17.85$ for males and $51.80 \pm 19.90$ for females) (Fig. 1).

Two hundred and seven (50.6\%) patients suffered a high fall, which was the most common injury mechanism. Eighty-five $(20.8 \%)$ patients were injured in low falls, which was the second most common injury mechanism (Table 1).

The most common injury was lumbar spine injury; 196 (48\%) patients suffered isolated lumbar spine

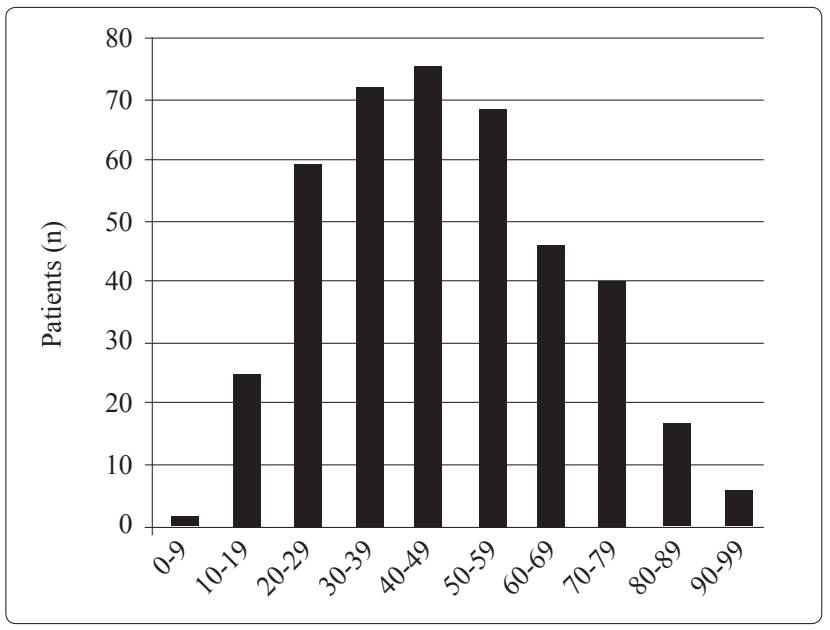

Fig. 1. Age distribution of patients.

injury. Thoracal spine injuries were the second most common injuries (Table 2). Spinal fractures were observed in $375(91.7 \%)$ patients; $27(6.6 \%)$ had spinal dislocations and $7(1.7 \%)$ had combined fractures and dislocations. Lumbar spinal injuries $(p=0.00011)$ were

Table 1. Injury mechanisms

\begin{tabular}{lcc}
\hline & $\mathrm{n}$ & $\%$ \\
\hline High fall & 207 & 50.6 \\
Low fall & 85 & 20.8 \\
Pedestrian accidents & 35 & 8.6 \\
Automobile accidents & 57 & 13.9 \\
Motorcycle accidents & 11 & 2.7 \\
Sport injuries & 14 & 3.4 \\
Total & 409 & 100 \\
\hline
\end{tabular}

Table 2. Injury level

\begin{tabular}{lcc}
\hline & $\mathrm{n}$ & $\%$ \\
\hline Cervical & 79 & 19.3 \\
Thoracal & 120 & 29.3 \\
Lumbar & 196 & 48.0 \\
Cervical and thoracal & 6 & 1.5 \\
Cervical and lumbar & 1 & 0.2 \\
Thoracal and lumbar & 7 & 1.7 \\
Total & 409 & 100 \\
\hline
\end{tabular}

Table 3. Injury type and injury level relation

\begin{tabular}{|c|c|c|c|c|c|c|}
\hline \multirow[b]{2}{*}{ High fall } & \multicolumn{2}{|c|}{ Cervical } & \multicolumn{2}{|c|}{ Thoracal } & \multicolumn{2}{|c|}{ Lumbar } \\
\hline & 28 & $\mathrm{p}=0.99$ & 67 & $\mathrm{p}=0.531$ & 123 & $\mathrm{p}=0.00011$ \\
\hline Low fall & 9 & $\mathrm{p}=0.993$ & 41 & $\mathrm{p}=0.003$ & 39 & $\mathrm{p}=0.465$ \\
\hline Pedestrian & 13 & $\mathrm{p}=0.027$ & 9 & $\mathrm{p}=0.352$ & 14 & $\mathrm{p}=0.289$ \\
\hline Automobile & 26 & $\mathrm{p}=0.00001$ & 17 & $\mathrm{p}=0.548$ & 18 & $\mathrm{p}=0.004$ \\
\hline Motorcycle & 3 & $\mathrm{p}=0.706$ & 5 & $\mathrm{p}=0.52$ & 3 & $\mathrm{p}=0.22$ \\
\hline Sports & 7 & $\mathrm{p}=0.014$ & 0 & & 7 & $\mathrm{p}=0.997$ \\
\hline
\end{tabular}




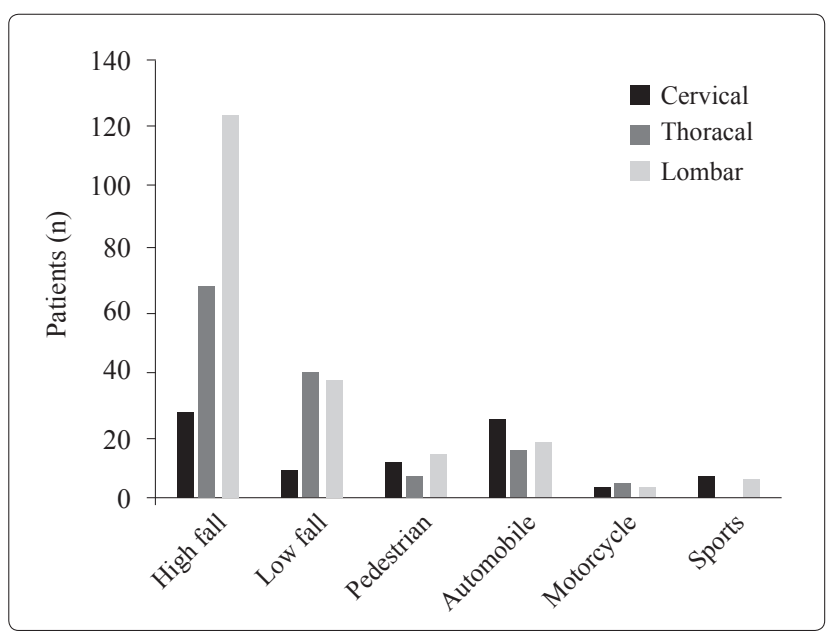

Fig. 2. Trauma mechanism and TSCI level relation.

observed at a higher rate in high falls, while low fall was a significant mechanism for thoracal spine injuries $(\mathrm{p}=0.003)$. Automobile accidents had a significant relation with cervical $(\mathrm{p}=0.00001)$ and lumbar $(\mathrm{p}=0.004)$ spinal injuries. Sports-related injuries $(\mathrm{p}=0.014)$ had a significant relation with cervical spinal injuries (Table 3, Fig. 2).

The most common season for TSCI was summer (Fig. 3). Three hundred and forty-four patients were classified as ASIA E and 65 patients were classified as ASIA A to D. Three hundred and twenty-nine (80.4\%) patients underwent surgical intervention. Eighty (19.6\%) patients were treated conservatively.

\section{DISCUSSION}

Kadıköy is one of the most culturally and economically developed parts of Turkey, and as such, it has unique features in spinal trauma etiology. In our study, the average age for TSCI was $46.82 \pm 19.05$ years (Fig. 1 ) and the male to female ratio was 1.6. Prior studies have shown a lower mean age and a male to female ratio of 2.5 to $4.4 .^{[4,5]}$ It was considerably lower in our study. The active participation of women in the social environment makes them more vulnerable to TSCI.

Studies usually show automobile accidents as the major cause of TSCI. ${ }^{[5,6]}$ While others have reported falls as the primary cause of TSCI. ${ }^{[7]}$ In our study, the most common cause of injury was high falls, while automobile accidents had a lesser role in the etiology (Table 1). Use of automobiles is very common. Numerous traffic accidents occur in Kadıköy daily, but high-speed traffic accidents are rare due to the heavy traffic. Furthermore, the population usually uses technologically advanced cars, and because of strict controls, vehicle occupants are forced to use seatbelts.

Recent studies show cervical spinal injury as the most common injury level. ${ }^{[1,4,8]}$ Different behavior

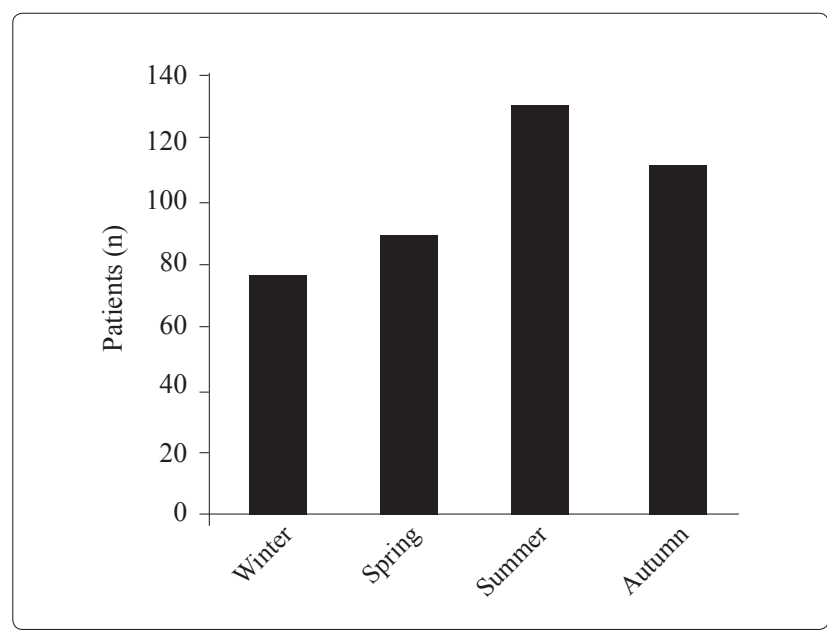

Fig. 3. Seasonal distribution of injuries.

patterns in different populations can affect the spinal cord injury etiology. ${ }^{[8]}$ Karacan et al ${ }^{[4]}$ found that the most common levels of injury were T12 and L1. In our study, the most common injury was lumbar spine injury. Levels of injury also had differing features due to differences in the most common trauma mechanisms. Although cervical injuries were higher in automobile accidents $(p=0.00001)$, the ratio of automobile accident-related TSCI was less than reported in other studies. The cervical injury ratio of the population has decreased due to a decrease in the number of automobile accident-related TSCIs. This is an innovation in the prevention of TSCI. The former major cause of TSCI has moved to the background due to lower speeds, better car technology and seatbelt use.

Lumbar spinal injuries $(\mathrm{p}=0.00011)$ were higher in high falls. High falls were the most common cause of TSCI. High fall has emerged as the leading cause as the incidence of automobile-related TSCIs has decreased. As the reasons for the falls were not recorded in patient files, our retrospective study design could not reveal the causes of the high falls.

Low fall was a significant mechanism for thoracal spine injuries $(\mathrm{p}=0.003)$, and was the second most common mechanism of TSCI. The average age of patients suffering low fall was $68.13 \pm 13.34$ years. When compared to the whole population, this population was older $(\mathrm{p}<0.05)$. As the elderly population grows, TSCI incidence will proportionally increase in this more challenging age group.

In conclusion, the effects of the city environment cause changes in the epidemiology of spinal trauma. In view of the aging population, an increase in the prevalence and modification in epidemiological features of spinal trauma can be expected.

Conflict-of-interest issues regarding the authorship or article: None declared. 


\section{REFERENCES}

1. Knútsdóttir S, Thórisdóttir H, Sigvaldason K, Jónsson H Jr, Björnsson A, Ingvarsson P. Epidemiology of traumatic spinal cord injuries in Iceland from 1975 to 2009. Spinal Cord 2012;50:123-6.

2. Ackery A, Tator C, Krassioukov A. A global perspective on spinal cord injury epidemiology. J Neurotrauma 2004;21:1355-70.

3. Schoenfeld AJ, Sielski B, Rivera KP, Bader JO, Harris MB. Epidemiology of cervical spine fractures in the US military. Spine J 2012;12:777-83.

4. Karacan I, Koyuncu H, Pekel O, Sümbüloglu G, Kirnap M, Dursun H, et al. Traumatic spinal cord injuries in Turkey: a nation-wide epidemiological study. Spinal Cord 2000;38:697-701.
5. Lenehan B, Street J, Kwon BK, Noonan V, Zhang H, Fisher $\mathrm{CG}$, et al. The epidemiology of traumatic spinal cord injury in British Columbia, Canada. Spine (Phila Pa 1976) 2012;37:321-9.

6. Draulans N, Kiekens C, Roels E, Peers K. Etiology of spinal cord injuries in Sub-Saharan Africa. Spinal Cord 2011;49:1148-54.

7. Couris CM, Guilcher SJ, Munce SE, Fung K, Craven BC, Verrier M, et al. Characteristics of adults with incident traumatic spinal cord injury in Ontario, Canada. Spinal Cord 2010;48:39-44

8. Tuğcu I, Tok F, Yılmaz B, Göktepe AS, Alaca R, Yazıcıŏlu $\mathrm{K}$, et al. Epidemiologic data of the patients with spinal cord injury: seven years' experience of a single center. Ulus Travma Acil Cerrahi Derg 2011;17:533-8. 